SLAC-PUB-15356

January 2013

\title{
PERFORMANCE METRICS FOR SAFE LASER OPERATIONS AT SLAC NATIONAL ACCELERATOR LABORATORY ${ }^{1}$
}

\author{
Paper \# 203
}

\author{
Michael Woods \\ SLAC National Accelerator Laboratory, \\ 2575 Sand Hill Rd., Menlo Park, CA 94025
}

\begin{abstract}
Two types of laser surveys are used at SLAC to help assess the lab's laser safety program and practices. The first survey is an annual questionnaire completed by laser operators at the lab to help assess safe laser practices and the effectiveness of the laser safety program. The second survey is completed by laser operators when they receive approval for one of the following: a new or revised laser safety document, a laser service subcontractor visit, or annual laser lab operation. An overview of these surveys is presented as well as results for some of the specific questions. Additional performance metrics are also described, which are based on quarterly tabulations of statistics for laser operations; these include the number of laser operators and lasers and laser labs, laser training evaluations, laser operations approvals given, Laser Safety Officer (LSO) visits to laser labs, and any incidents or lessons learned/best practices reports.
\end{abstract}

\section{Overview of laser survey questionnaires}

One questionnaire is completed annually by SLAC's laser operators. It includes questions on the following:

i. quality and effectiveness of training (site-specific training as well as laser program training), supervision, safety oversight and assistance, engineering controls, administrative procedures, and personnel protective equipment (PPE);

ii. observations of safe practices and compliance with requirements for safety procedures and laser eyewear PPE;

iii. estimates of rates for near misses and injuries; and

iv. estimates of probabilities to report near misses and injuries.
The second questionnaire is completed by laser operators receiving approval for one of the following:

i. annual laser operation approval,

ii. new/revised laser safety procedure document, or

iii. a laser service subcontractor visit.

It includes questions on the quality and timeliness of the approval process, and if the associated review comments and action items were appropriate.

The surveys are used to identify areas of risk or concern which need attention or additional resources. The information gathered helps determine appropriate corrective actions and improvement opportunities. Some of the survey results are used as performance metrics that can be tracked for determining trends. Survey results are made available to laser personnel and to SLAC's safety management.

The annual operator survey was developed as part of a 2011 internal laser safety management review that focused on risk assessment: assessing risk for a laser injury accident and risk for meeting science program goals, and then identifying ways to mitigate these risks. The laser operations approval survey was subsequently developed to assess the approval process for laser operations and the customer satisfaction associated with that.

Both types of survey questionnaires are multiple choice with allowance for additional comments for each question. They are conducted with SurveyMonkey [1], which provides an easy interface for developing questions and analysing responses.

The annual laser operator survey takes 15-20 minutes to complete, while the laser operations approval survey takes about 5 minutes. Development of the surveys and subsequent analysis of the results is done primarily

\footnotetext{
${ }^{1}$ Contributed to the 2013 International Laser Safety Conference, Orlando, FL; http://www.lia.org/conferences/ilsc.
} 
by the LSO, but with discussion and input from SLAC’s laser safety committee.

\section{Annual Laser Operator Survey}

The annual survey starts with questions on the operator's demographics to determine their affiliation with SLAC (ex. employee or student), which of the lab's directorate programs they work in, their laser expertise level, and whether they are a laser worker or a laser lab supervisor. This survey is anonymous. Subsequent questions ask the operator to evaluate SLAC's laser safety program and training, and to evaluate the safety of laser operations. Most survey questions give a statement and then ask how accurate the statement is. Examples of these questions and responses for the 2012 survey are given in Table 1. There were 79 survey responses received from SLAC's population of 200 active laser operators during the 2week period the survey was conducted in July 2012.

Table 1: Sample of survey questions and results from SLAC's 2012 Annual Laser Operator Survey.

\begin{tabular}{|c|c|c|c|c|c|}
\hline Survey statement & $\begin{array}{c}\text { Strongly } \\
\text { Agree }\end{array}$ & Agree & Neutral & Disagree & $\begin{array}{l}\text { Strongly } \\
\text { Disagree }\end{array}$ \\
\hline $\begin{array}{lllll}\text { Q9 Available equipment and laser facility } \\
\text { configuration are good and effective. }\end{array}$ & 33 & 33 & 5 & 0 & 0 \\
\hline $\begin{array}{l}\text { Q10 Engineering controls (interlocks, safety shutters, } \\
\text { barriers, enclosures ...) are well done and effective. }\end{array}$ & 36 & 26 & 9 & 0 & 0 \\
\hline $\begin{array}{l}\text { Q11 The Standard Operating Procedures (SOP) } \\
\text { document is used: i) for documenting laser hazards } \\
\text { and controls, ii) for initial training, and iii) as a } \\
\text { reference document. It meets these goals well. }\end{array}$ & 29 & 28 & 9 & 6 & 0 \\
\hline $\begin{array}{l}\text { Q13 Laser operators work safely, adhering to safe } \\
\text { practices described in the SOP document and the Core } \\
\text { Laser Safety Practices poster. }\end{array}$ & 37 & 30 & 4 & 0 & 0 \\
\hline $\begin{array}{l}\text { Q14 Laser eyewear requirements + available eyewear: } \\
\text { these are implemented well and are effective; it is easy } \\
\text { to comply with the laser eyewear requirements. }\end{array}$ & 41 & 27 & 3 & 0 & 0 \\
\hline $\begin{array}{l}\text { Q15 Laser eyewear requirements are always adhered } \\
\text { to. I am not aware of laser operators intentionally or } \\
\text { mistakenly violating a laser eyewear requirement. }\end{array}$ & 42 & 22 & 5 & 2 & 0 \\
\hline $\begin{array}{l}\text { Q18 You perceive laser safety more as an integral part } \\
\text { of laser operations than as an added burden. }\end{array}$ & 32 & 33 & 6 & 1 & 0 \\
\hline $\begin{array}{l}\text { Q19 Laser Lessons Learned classroom course. If } \\
\text { completed within last year: this course effectively } \\
\text { meets its goals to inform laser operators about laser } \\
\text { accidents and measures to take to avoid them. }\end{array}$ & 17 & 29 & 5 & 0 & 0 \\
\hline $\begin{array}{l}\text { Q20 General Laser Safety web-based course. If } \\
\text { completed within last year: this course effectively } \\
\text { meets its goals to educate laser operators about laser } \\
\text { hazards and controls and safety requirements. }\end{array}$ & 14 & 28 & 6 & 1 & 0 \\
\hline $\begin{array}{l}\text { Q35 Safe Laser Alignment Practical classroom course. } \\
\text { If completed within last year: this instruction was } \\
\text { good and adequately addressed core laser safety } \\
\text { practices and ways to avoid common mistakes that } \\
\text { might lead to an injury. }\end{array}$ & 16 & 20 & 3 & 0 & 0 \\
\hline $\begin{array}{l}\text { Q39 Site-specific On-the-Job Training (OJT) was well } \\
\text { done and adequately prepared me to work } \\
\text { unsupervised in the laser lab (for those who have } \\
\text { received permission to work unsupervised). }\end{array}$ & 23 & 21 & 8 & 2 & 1 \\
\hline $\begin{array}{l}\text { Q21 Oversight and assistance by the LSO are effective } \\
\text { and well done. }\end{array}$ & 33 & 34 & 5 & 0 & 0 \\
\hline $\begin{array}{l}\text { Q32 Laser safety requirements are appropriate and do } \\
\text { not impede achieving science program technical goals. }\end{array}$ & 18 & 30 & 12 & 5 & 1 \\
\hline $\begin{array}{l}\text { Q33 Laser safety requirements are appropriate and do } \\
\text { not impede meeting science program schedule goals. }\end{array}$ & 13 & 26 & 21 & 6 & 0 \\
\hline
\end{tabular}


Additional results from Survey questions Q16, Q25Q28, and Q30-Q31 are shown in the Appendix. Q16 is a follow-up to Q15 in Table 1 above about the potential for a hazardous exposure for any observed eyewear requirement violation. Questions Q25-Q28 ask for estimates of the frequency for an injury or near miss incident and the probability that these would be reported. Questions Q30-Q31 ask which types of controls (including training, supervision, available equipment and review/approval process) are most effective - results from these questions indicate, for example, that available equipment and facility configuration are very important.

The survey allows the option to give additional comments for each evaluation question and at the end of the survey to provide additional comments about any unnecessary controls requirements, risk for a laser injury incident or risk that laser safety requirements present to science program goals. Some examples of comments received in the 2012 survey are given in Table 2.

Table 2: Sample of comments from SLAC’s 2012 Annual Laser Operator Survey.

\begin{tabular}{|c|c|}
\hline Survey statement & Comment \\
\hline $\begin{array}{l}\text { Q11 The SOP document is used: i) for } \\
\text { documenting laser hazards and controls, ii) } \\
\text { for initial training, and iii) as a reference } \\
\text { document. It meets these goals well. }\end{array}$ & $\begin{array}{l}\text { - Not as useful as good OJT } \\
\text { - Students will not read the SOP carefully, or read and forget. The } \\
\text { OJT part is the actual way the information of the SOP is absorbed } \\
\text { by the students, and what keeps the work safe. } \\
\text { - We are keeping the SOP updated as the set-up is modified. }\end{array}$ \\
\hline $\begin{array}{l}\text { Q14 Laser eyewear requirements + } \\
\text { available eyewear: these are implemented } \\
\text { well and are effective; it is easy to comply } \\
\text { with the laser eyewear requirements. }\end{array}$ & $\begin{array}{l}\text { - I am a fan of high VLT (visible light transmission) goggles. We } \\
\text { could not use them at my last institution. They make a really big } \\
\text { difference in motivation to comply with eyewear requirements. } \\
\text { - Some facilities are not crystal clear on which eyewear is required } \\
\text { for a particular mode. I would like to see a 1-1 naming scheme } \\
\text { for what is on the electronic display sign and the eyewear label. }\end{array}$ \\
\hline $\begin{array}{l}\text { Q35 Laser Alignment Practical course was } \\
\text { good. It adequately addressed core laser } \\
\text { safety practices and ways to avoid common } \\
\text { mistakes that might lead to an injury. }\end{array}$ & $\begin{array}{l}\text { - This is an excellent course - I think it was the most valuable } \\
\text { training I've received at SLAC in any way (and the best by far - } \\
\text { most other training cover things that I basically already know) } \\
\text { - I would like more of this kind of training as a beginner. }\end{array}$ \\
\hline $\begin{array}{l}\text { Q32, Q33 Laser safety requirements are } \\
\text { appropriate and do not impede achieving } \\
\text { science program goals. }\end{array}$ & $\begin{array}{l}\text { - SLAC is making progress, but this is one of the many areas that } \\
\text { impede meeting science program goals. } \\
\text { - Vastly improved over the past, but still a burden compared to a } \\
\text { University lab. } \\
\text { - I think requirements are appropriate, but they do without question } \\
\text { impede achieving science goals. }\end{array}$ \\
\hline
\end{tabular}

The 2012 survey responses give good ratings for the laser safety program and safe practices, but some areas of concern are noted:

- $10-15 \%$ of respondents reported at least one observation of an eyewear violation (includes both intentional and by mistake). Most of these indicated no plausible possibility for hazardous exposure from the occurrence, and the rest reported $<<1 \%$ probability for a hazardous exposure. (Survey Q15-16)

- Only $75 \%$ of respondents think probability is $>80 \%$ that a laser eye injury would be reported and only $42 \%$ think probability is $>80 \%$ that a near miss would be reported. (Survey Q26-27)

- For estimating frequency of near miss events, median response is $1-2$ per year for every 100 laser operators at SLAC. The median response for estimating frequency of an eye injury per 100 laser operators was one every 5-10 years. (Survey Q25, Q28)

- $18 \%$ were neutral or disagreed that site-specific OJT was well done for giving adequate preparation to work unsupervised. (Survey Q39)

- Relative importance of administrative procedures was less than expected. (Survey Q30)

A comparison of results between the 2011 and 2012 surveys was done. Improved results in some areas are noted in Table 3. These include improvements in the perception that laser safety is an integral part of laser operations and that safety oversight does not impede science program goals. There were no areas showing worse results for 2012. At a meeting of the laser safety committee to discuss the survey results, the following reasons were thought to be likely factors for positive trends in laser safety: education and training of SLAC 
laser staff, cultural changes within SLAC's laser labs, and maturity of SLAC's laser labs as they move from commissioning to operation with reduced documentation workload (SLAC laser operations have more than doubled in the last three years).

Table 3: Comparison of results from SLAC’s 2011 and 2012 Annual Laser Operator Surveys.

\begin{tabular}{|l|c|c|}
\hline \multicolumn{1}{|c|}{ Survey statement } & $\mathbf{2 0 1 1}$ & 2012 \\
\hline $\begin{array}{l}\text { I perceive laser safety more as an integral part of laser } \\
\text { operations than as an added burden. }\end{array}$ & $\begin{array}{c}60.4 \% \text { (Strongly) Agree } \\
12.3 \% \text { (Strongly) Disagree }\end{array}$ & $\begin{array}{c}90.2 \% \text { (Strongly) Agree } \\
1.4 \% \text { (Strongly) Disagree }\end{array}$ \\
\hline $\begin{array}{l}\text { Laser safety requirements do not impede meeting } \\
\text { science program schedule goals. }\end{array}$ & $35 \%$ (Strongly) Agree \\
\hline $\begin{array}{l}\text { Improvements are needed in oversight and laser safety } \\
\text { requirements to reduce risk for meeting science } \\
\text { program technical/schedule goals. }\end{array}$ & $\begin{array}{c}59.1 \% \text { (Strongly) Agree } \\
9.1 \% \text { (Strongly) Disagree }\end{array}$ \\
\hline $\begin{array}{l}\text { Improvements are needed in available laser safety } \\
\text { equipment or laser facility configuration to reduce risk } \\
\text { for meeting science program technical/schedule goals }\end{array}$ & $16.4 \%$ Agree & $3.2 \%$ Agree \\
\hline
\end{tabular}

\section{Laser Operations Approval Survey}

This survey is not anonymous and asks for the person's name and which laser lab is involved. It has questions on the demographics for the person completing the survey to determine their affiliation with SLAC and which of the lab's directorate programs they work in. It asks what type of laser approval was issued (ex. SOP revision or service subcontractor visit). The evaluation questions have a similar format and ask how well the person agrees with statements about the requirements, quality and effectiveness of the approval process. Optional comment fields are included for each of the evaluation questions.

This survey was launched in May of 2012 and results are given in Table 4 for 25 surveys completed between
May-December, 2012. The survey results give very high satisfaction ratings for the approval review process, which helps alleviate concerns on this due to results in the 2011 annual laser operator survey and other related informal comments. One survey response for a service visit approval did comment that a lot of unnecessary top management approvals were needed. The dissatisfaction though was because of purchasing and line management approval requirements because it was an emergency repair that needed immediate approval. This and some of the other comments received are given in Table 5 . The comments are very useful and can lead to follow-up clarifications, and to improvements in process requirements or in lab implementation.

Table 4: Survey questions and results from SLAC’s Laser Approvals Survey, for surveys completed between May-December, 2012.

\begin{tabular}{|c|c|c|c|c|c|}
\hline Survey statement & $\begin{array}{l}\text { Strongly } \\
\text { Agree }\end{array}$ & Agree & Neutral & Disagree & $\begin{array}{l}\text { Strongly } \\
\text { Disagree }\end{array}$ \\
\hline $\begin{array}{l}\text { The laser safety program requirements for this } \\
\text { approval are appropriate for addressing laser safety and } \\
\text { for meeting SLAC's Work Planning and Control } \\
\text { requirements. }\end{array}$ & 13 & 11 & 0 & 0 & 1 \\
\hline $\begin{array}{l}\text { Communication with LSO on the approval request was } \\
\text { clear and timely. }\end{array}$ & 18 & 7 & 0 & 0 & 0 \\
\hline $\begin{array}{l}\text { Review by LSO and associated comments/action items } \\
\text { were appropriate and responsive to our needs. }\end{array}$ & 18 & 7 & 0 & 0 & 0 \\
\hline Approval was professional and timely. & 18 & 7 & 0 & 0 & 0 \\
\hline The overall review/approval process was satisfactory. & 12 & 12 & 0 & 1 & 0 \\
\hline
\end{tabular}


Table 5: Sample of comments from SLAC’s Laser Approvals Survey.

\begin{tabular}{|c|c|}
\hline Survey statement & Comment (survey \# indicated so can correlate comments) \\
\hline $\begin{array}{l}\text { The laser safety program requirements for } \\
\text { this approval are appropriate for addressing } \\
\text { laser safety and for meeting SLAC's Work } \\
\text { Planning and Control requirements. }\end{array}$ & $\begin{array}{l}\text { 1. A lot of unnecessary top management approvals (service visit) } \\
\text { 17. It generally takes roughly a week to get all of the safety } \\
\text { documentation and forms together if starting the red folder from } \\
\text { scratch. (service visit) }\end{array}$ \\
\hline Approval was professional and timely. & $\begin{array}{l}\text { 17. This went fast because it was more or less identical to a recent } \\
\text { previous laser visit. (service visit) }\end{array}$ \\
\hline $\begin{array}{l}\text { The overall review/approval process was } \\
\text { satisfactory. }\end{array}$ & $\begin{array}{l}\text { 8. As far as the laser safety is concerned, but the approval process } \\
\text { on the purchasing side is another story entirely. (service visit) } \\
\text { 18. Process was very complete leading to a well-implemented laser } \\
\text { safety system and laboratory culture. (new SOP/annual) }\end{array}$ \\
\hline $\begin{array}{l}\text { Please give any additional comments, such } \\
\text { as recommendations for improvements to } \\
\text { the review and approval process: }\end{array}$ & $\begin{array}{l}\text { 1. Please remove top management approval (service visit) } \\
\text { 6. Can SLAC allow the well-trained laser service engineer to } \\
\text { become a "SLAC laser operator" so they can do their job using } \\
\text { the SLAC employee policy? (service visit) } \\
\text { 11. The SOP's have become so full of legalese that I don't think they } \\
\text { are useful as a reference to someone new to that facility. (SOP } \\
\text { revision/annual) } \\
\text { 16. It would be very useful if we could arrange a Class } 4 \text { unattended } \\
\text { mode. The laser safety aspect of our beam time went very } \\
\text { smoothly otherwise. (safety document + short operation approval) } \\
\text { 17. Is there any way to get the service techs classified as subject } \\
\text { matter experts to reduce the pre-job briefing time? (service visit) } \\
\text { 22. There should be a } 1 \text { page SOP Abstract/Summary indicating the } \\
\text { operation modes. (new SOP/annual) }\end{array}$ \\
\hline
\end{tabular}

\section{Quarterly Performance Metrics}

In addition to the 2 types of survey questionnaires noted above, quarterly performance metrics are used to help assess SLAC's laser safety program and safe laser operations. These metrics are summarized in Table 6 in Appendix 2, with 2012 results given based on the quarterly compilations. The quarterly results can then be used for trending charts, such as those shown in Figures 8 and 9 in Appendix 2.

\section{Summary}

Good performance metrics are needed to assess the quality and effectiveness of a laser safety program, and to assess the safety of laser operations. This paper presented two survey questionnaires used for this purpose, whose results are communicated to laser personnel and lab safety management. Additional tabulated quarterly performance metrics were also described. Results from the surveys and quarterly metrics are used to identify ways to improve SLAC's laser safety program and to help laser personnel (particularly laser supervisors) identify ways to improve safe laser operations. Survey results and quarterly metrics also provide important information on the scope of laser operations and the associated risk, and on trends for the scope and risk.

\section{Acknowledgements}

Work supported by the U.S. Department of Energy under contract number DE-AC02-76SF00515.

\section{References}

[1] SurveyMonkey, http://www.surveymonkey.com/.

\section{Meet the Author}

Michael Woods, CLSO, is the Laser Safety Officer at the SLAC National Accelerator Laboratory. He is an Engineering Physicist, with a B.Sc. in Engineering Physics from Queen's University in Kingston, Ontario, Canada and a Ph.D. in High Energy Physics from the University of Chicago. He has spent 15 years as a researcher in experimental particle physics and accelerator physics, utilizing high power laser systems for photo-injectors, Compton polarimeters and electron beam diagnostics. He became SLAC LSO in 2008. He is a member of the ANSI Z136 SSC-1, TSC-4 and TSC-5 committees. 
APPENDIX 1: Results from Sample Questions in the 2012 SLAC Annual Laser Operator Survey

16. Laser Eyewear Practices (Part 2): If a laser eyewear requirement has been observed to be violated, whether intentional or by mistake, estimate the potential for a hazardous exposure of the most severe violation observed.

\begin{tabular}{|c|c|c|c|}
\hline & & $\begin{array}{c}\text { Response } \\
\text { Percent }\end{array}$ & $\begin{array}{l}\text { Response } \\
\text { Count }\end{array}$ \\
\hline $\begin{array}{r}\text { No violations observed, so no } \\
\text { related possibility for hazardous } \\
\text { exposure }\end{array}$ & $\square$ & $84.3 \%$ & 59 \\
\hline $\begin{array}{l}\text { Violation observed - no plausible } \\
\text { possibility for hazardous exposure }\end{array}$ & $\square$ & $11.4 \%$ & 8 \\
\hline $\begin{array}{r}\text { Violation observed - very low } \\
\text { possibility }(<<1 \%) \text { for hazardous } \\
\text { exposure }\end{array}$ & $\square$ & $4.3 \%$ & 3 \\
\hline $\begin{array}{l}\text { Violation observed - low possibility } \\
\quad(<2 \%) \text { for hazardous exposure }\end{array}$ & & $0.0 \%$ & 0 \\
\hline $\begin{array}{r}\text { Violation observed - possibility } \\
\text { existed }(>2 \%) \text { for hazardous } \\
\text { exposure }\end{array}$ & & $0.0 \%$ & 0 \\
\hline
\end{tabular}

Figure 1: Results from Question 16 in the Annual Laser Operator Survey.

25. Frequency of laser eye injuries at SLAC: For every 100 QLOs at SLAC - what is your best estimate for how often a single eye injury may occur from a laser accident to any of these laser operators?

\begin{tabular}{|c|c|c|c|}
\hline & & $\begin{array}{c}\text { Response } \\
\text { Percent }\end{array}$ & $\begin{array}{c}\text { Response } \\
\text { Count }\end{array}$ \\
\hline Less than one every 20 years & $\square$ & $14.5 \%$ & 10 \\
\hline One every $10-20$ years & $\square$ & $17.4 \%$ & 12 \\
\hline One every $5-10$ years & $\square$ & $27.5 \%$ & 19 \\
\hline One every $2-5$ years & $\square$ & $13.0 \%$ & 9 \\
\hline Approximately $1 /$ year & $\square$ & $11.6 \%$ & 8 \\
\hline Don't know & $\square$ & $15.9 \%$ & 11 \\
\hline
\end{tabular}

Figure 2: Results from Question 25 in the Annual Laser Operator Survey. 
26. Reporting laser eye injuries: What is your best estimate of the probability that a laser eye injury at SLAC would be reported if it occurred?

\begin{tabular}{|c|c|c|c|}
\hline & & $\begin{array}{c}\text { Response } \\
\text { Percent }\end{array}$ & $\begin{array}{c}\text { Response } \\
\text { Count }\end{array}$ \\
\hline$>95 \%$ & $\square$ & $53.6 \%$ & 37 \\
\hline$(80-95) \%$ & $\square$ & $21.7 \%$ & 15 \\
\hline$(50-80) \%$ & $\square$ & $10.1 \%$ & 7 \\
\hline$(25-50) \%$ & $\square$ & $2.9 \%$ & 2 \\
\hline$<25 \%$ & $\square$ & $2.9 \%$ & 2 \\
\hline Don't know & $\square$ & $8.7 \%$ & 6 \\
\hline
\end{tabular}

Figure 3: Results from Question 26 in the Annual Laser Operator Survey.

27. Reporting Near Misses: A Near Miss occurs when safety is compromised such that only one or no barriers are in place to prevent a laser eye injury. What is your best estimate of the probability that a Near Miss laser incident at SLAC would be reported if it occurred?

\begin{tabular}{|c|c|c|c|}
\hline & & $\begin{array}{c}\text { Response } \\
\text { Percent }\end{array}$ & $\begin{array}{c}\text { Response } \\
\text { Count }\end{array}$ \\
\hline$>95 \%$ & $\square$ & $10.1 \%$ & 7 \\
\hline$(80-95) \%$ & $\square$ & $31.9 \%$ & 22 \\
\hline $50-80) \%$ & $\square$ & $21.7 \%$ & 15 \\
\hline$(25-50) \%$ & $\square$ & $10.1 \%$ & 7 \\
\hline$<25 \%$ & $\square$ & $14.5 \%$ & 10 \\
\hline Don't know & $\square$ & $11.6 \%$ & 8 \\
\hline
\end{tabular}

Figure 4: Results from Question 27 in the Annual Laser Operator Survey.

28. Frequency of Near Misses at SLAC: For every 100 QLOs at SLAC - what is your best estimate for how often a near miss event may occur to any of these laser operators (see previous question for near miss definition)?

\begin{tabular}{|c|c|c|c|}
\hline & & $\begin{array}{c}\text { Response } \\
\text { Percent }\end{array}$ & $\begin{array}{c}\text { Response } \\
\text { Count }\end{array}$ \\
\hline Less than one every 10 years & 口 & $1.5 \%$ & 1 \\
\hline One every 2-10 years & $\square$ & $20.6 \%$ & 14 \\
\hline Approximately 1-2 per year & $\square$ & $33.8 \%$ & 23 \\
\hline Approximately 2-10/year & $\square$ & $14.7 \%$ & 10 \\
\hline More than $10 /$ year & $\square$ & $2.9 \%$ & 2 \\
\hline Don't know & $\square$ & $26.5 \%$ & 18 \\
\hline
\end{tabular}

Figure 5: Results from Question 28 in the Annual Laser Operator Survey. 


\begin{tabular}{|c|c|c|c|c|c|c|c|}
\hline & $\begin{array}{l}1 \text { - Most } \\
\text { Effective }\end{array}$ & 2 & 3 & 4 & $\begin{array}{l}5 \text { - Least } \\
\text { Effective }\end{array}$ & $\begin{array}{l}\text { Rating } \\
\text { Average }\end{array}$ & $\begin{array}{l}\text { Response } \\
\text { Count }\end{array}$ \\
\hline Engineering controls & $\begin{array}{c}43.1 \% \\
(28)\end{array}$ & $\begin{array}{c}24.6 \% \\
(16)\end{array}$ & $\begin{array}{c}21.5 \% \\
(14)\end{array}$ & $6.2 \%(4)$ & $4.6 \%(3)$ & 1.00 & 65 \\
\hline Administrative procedures & $4.6 \%(3)$ & $9.2 \%(6)$ & $\begin{array}{c}29.2 \% \\
(19)\end{array}$ & $\begin{array}{c}21.5 \% \\
(14)\end{array}$ & $\begin{array}{c}35.4 \% \\
(23)\end{array}$ & 1.00 & 65 \\
\hline Laser eyewear & $\begin{array}{c}33.3 \% \\
(22)\end{array}$ & $\begin{array}{c}42.4 \% \\
(28)\end{array}$ & $12.1 \%(8)$ & $7.6 \%(5)$ & $4.5 \%(3)$ & 1.00 & 66 \\
\hline $\begin{array}{r}\text { ESH-provided training (ESH131 or } \\
\text { ESH253) }\end{array}$ & $3.1 \%(2)$ & $7.7 \%(5)$ & $13.8 \%(9)$ & $\begin{array}{c}32.3 \% \\
(21)\end{array}$ & $\begin{array}{c}43.1 \% \\
(28)\end{array}$ & 1.00 & 65 \\
\hline $\begin{array}{l}\text { Site-specific and supervisor- } \\
\text { provided training (SOP, OJT, } \\
\text { posted procedures, ESH 253PRA) }\end{array}$ & $\begin{array}{c}16.9 \% \\
(11)\end{array}$ & $\begin{array}{c}16.9 \% \\
(11)\end{array}$ & $\begin{array}{c}24.6 \% \\
(16)\end{array}$ & $\begin{array}{c}30.8 \% \\
(20)\end{array}$ & $10.8 \%(7)$ & 1.00 & 65 \\
\hline
\end{tabular}

Figure 6: Results from Question 30 in the Annual Laser Operator Survey.

\begin{tabular}{|c|c|c|c|c|c|c|c|}
\hline & $\begin{array}{l}1 \text { - Most } \\
\text { Effective }\end{array}$ & 2 & 3 & 4 & $\begin{array}{l}5 \text { - Least } \\
\text { Effective }\end{array}$ & $\begin{array}{l}\text { Rating } \\
\text { Average }\end{array}$ & $\begin{array}{l}\text { Response } \\
\text { Count }\end{array}$ \\
\hline $\begin{array}{r}\text { ESH/LSO oversight and assistance } \\
\text { for laser safety }\end{array}$ & $4.6 \%(3)$ & $9.2 \%(6)$ & $\begin{array}{c}26.2 \% \\
(17)\end{array}$ & $\begin{array}{c}30.8 \% \\
(20)\end{array}$ & $\begin{array}{c}29.2 \% \\
(19)\end{array}$ & 1.00 & 65 \\
\hline $\begin{array}{r}\text { Supervision of laser facility by } \\
\text { SLSO }\end{array}$ & $\begin{array}{c}15.6 \% \\
(10)\end{array}$ & $\begin{array}{c}37.5 \% \\
(24)\end{array}$ & $\begin{array}{c}20.3 \% \\
(13)\end{array}$ & $\begin{array}{c}17.2 \% \\
(11)\end{array}$ & $9.4 \%(6)$ & 1.00 & 64 \\
\hline $\begin{array}{r}\text { Line management resources and } \\
\text { assistance for laser safety (either } \\
\text { budget or personnel) }\end{array}$ & $3.2 \%(2)$ & $\begin{array}{c}19.0 \% \\
(12)\end{array}$ & $\begin{array}{c}22.2 \% \\
(14)\end{array}$ & $\begin{array}{c}25.4 \% \\
(16)\end{array}$ & $\begin{array}{c}30.2 \% \\
(19)\end{array}$ & 1.00 & 63 \\
\hline $\begin{array}{l}\text { Available laser safety equipment or } \\
\text { laser facility configuration }\end{array}$ & $\begin{array}{c}74.2 \% \\
(49)\end{array}$ & $10.6 \%(7)$ & $12.1 \%(8)$ & $1.5 \%(1)$ & $1.5 \%(1)$ & 1.00 & 66 \\
\hline $\begin{array}{r}\text { Laser safety review and approval } \\
\text { process }\end{array}$ & $1.6 \%(1)$ & $\begin{array}{c}25.0 \% \\
(16)\end{array}$ & $\begin{array}{c}20.3 \% \\
(13)\end{array}$ & $\begin{array}{c}25.0 \% \\
(16)\end{array}$ & $\begin{array}{c}28.1 \% \\
(18)\end{array}$ & 1.00 & 64 \\
\hline
\end{tabular}

Figure 7: Results from Question 31 in the Annual Laser Operator Survey. 


\section{APPENDIX 2: Examples of Quarterly Performance Metrics}

Table 6: Laser Safety Performance Metrics tabulated quarterly at SLAC (results given for the 2012 calendar year)

\begin{tabular}{|c|c|c|}
\hline Category & Performance Metric & $\begin{array}{c}2012 \\
\text { Result }\end{array}$ \\
\hline \multirow{2}{*}{$\begin{array}{ll}1 . & \text { Laser Facilities } \\
\text { (Class 3B or Class 4) }\end{array}$} & 1.1. Number of operating laser facilities & 28 \\
\hline & 1.2. Number of lasers (Class 3B, Class 4) & 145 \\
\hline \multirow{2}{*}{ 2. $\quad$ Laser Operators } & 2.1. Total number of laser operators & 250 \\
\hline & 2.2. Number of new operators approved & 71 \\
\hline \multirow[t]{5}{*}{ 3. Training Completed } & $\begin{array}{l}\text { 3.1. Number of operators with training overdue at end of } \\
\text { reporting period }\end{array}$ & 2 \\
\hline & $\begin{array}{l}\text { 3.2. Personnel completing general laser safety class (3-hr } \\
\text { web-based course; 3-yr refresher training requirement) }\end{array}$ & 115 \\
\hline & $\begin{array}{l}\text { 3.3. Personnel completing laser lessons learned class (90- } \\
\text { minute classroom course; no refresher requirement) }\end{array}$ & 96 \\
\hline & $\begin{array}{l}\text { 3.4. Personnel completing laser alignment practical (1-3 hr } \\
\text { classroom course; no refresher requirement) }\end{array}$ & 51 \\
\hline & $\begin{array}{l}\text { 3.5. Personnel completing laser supervisor training (2.5-hr } \\
\text { classroom course; 3-yr refresher training requirement) }\end{array}$ & 25 \\
\hline \multirow{7}{*}{$\begin{array}{l}\text { 4. Training Evaluations } \\
\text { (A 1-5 scale is used for } \\
\text { the effectiveness/quality } \\
\text { of the training; } 5 \text { means } \\
\text { strongly agree that the } \\
\text { training achieved the } \\
\text { stated goal, } 3 \text { is neutral } \\
\text { and } 1 \text { means strongly } \\
\text { disagree that the training } \\
\text { achieved the stated goal.) }\end{array}$} & $\begin{array}{l}\text { 4.1. General laser safety class. Take away concepts that will } \\
\text { help me work safely. }\end{array}$ & 4.6 \\
\hline & $\begin{array}{l}\text { 4.2. Laser Lessons Learned class. Course materials were } \\
\text { comprehensive and complete. }\end{array}$ & 4.3 \\
\hline & $\begin{array}{l}\text { 4.3. Laser Lessons Learned class. Course will adequately } \\
\text { prepare worker for tasks. }\end{array}$ & 3.9 \\
\hline & $\begin{array}{l}\text { 4.4. Laser Alignment Practical class. Course materials are } \\
\text { comprehensive and complete. }\end{array}$ & 4.5 \\
\hline & $\begin{array}{l}\text { 4.5. Laser Alignment Practical class. Course will adequately } \\
\text { prepare worker for tasks. }\end{array}$ & 4.2 \\
\hline & $\begin{array}{l}\text { 4.6. Laser Supervisor Safety class. Course materials are } \\
\text { comprehensive and complete. }\end{array}$ & 4.2 \\
\hline & $\begin{array}{l}\text { 4.7. Laser Supervisor Safety class. Course will adequately } \\
\text { prepare worker for tasks. }\end{array}$ & 4.0 \\
\hline 5. Service Subcontractors & 5.1. Number of laser service subcontractor visits & 12 \\
\hline \multirow[t]{3}{*}{$\begin{array}{l}\text { 6. Incidents or Lessons } \\
\text { Learned/Best Practices }\end{array}$} & $\begin{array}{l}\text { 6.1. Number of laser incidents resulting in a DOE ORPS } \\
\text { report }\end{array}$ & 1 \\
\hline & $\begin{array}{l}\text { 6.2. Number of lessons learned events, including incident } \\
\text { reports }\end{array}$ & 5 \\
\hline & $\begin{array}{l}\text { 6.3. Number of best practice reports or identified in a lessons } \\
\text { learned event. }\end{array}$ & 3 \\
\hline \multirow[t]{3}{*}{ 7. Laser Safety Action Items } & 7.1. Number of new items & 19 \\
\hline & 7.2. Number of items completed & 22 \\
\hline & 7.3. Number of items overdue & 0 \\
\hline \multirow{3}{*}{$\begin{array}{l}\text { 8. LSO and Laser Safety } \\
\text { Committee }\end{array}$} & 8.1. Number of LSO visits to laser labs & 174 \\
\hline & 8.2. Number of LSC meetings held & 8 \\
\hline & 8.3. Number of LSO Memos or Laser Safety Technotes & 8 \\
\hline
\end{tabular}




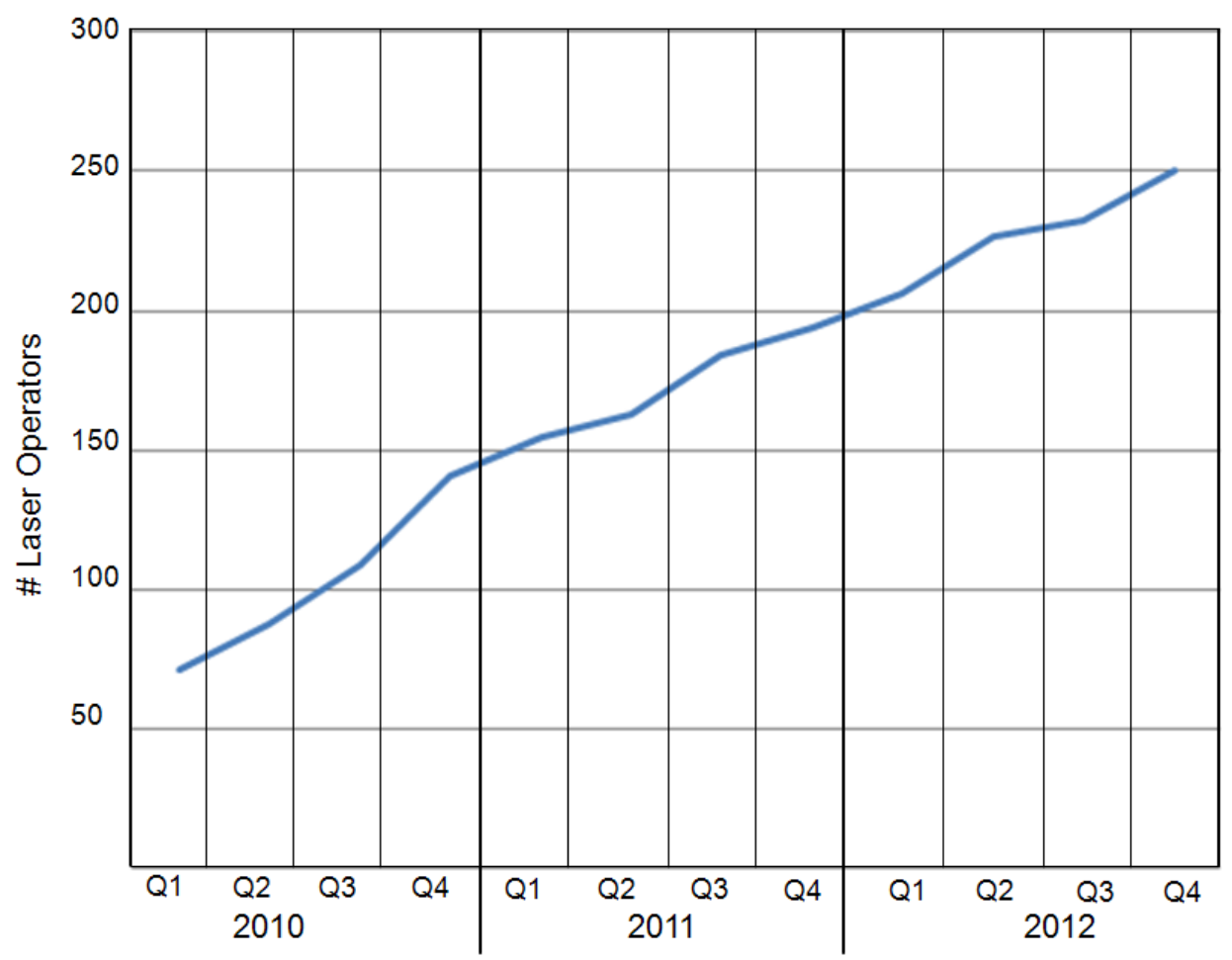

Figure 8: Number of laser operators approved to work with Class 3B or Class 4 lasers at SLAC.

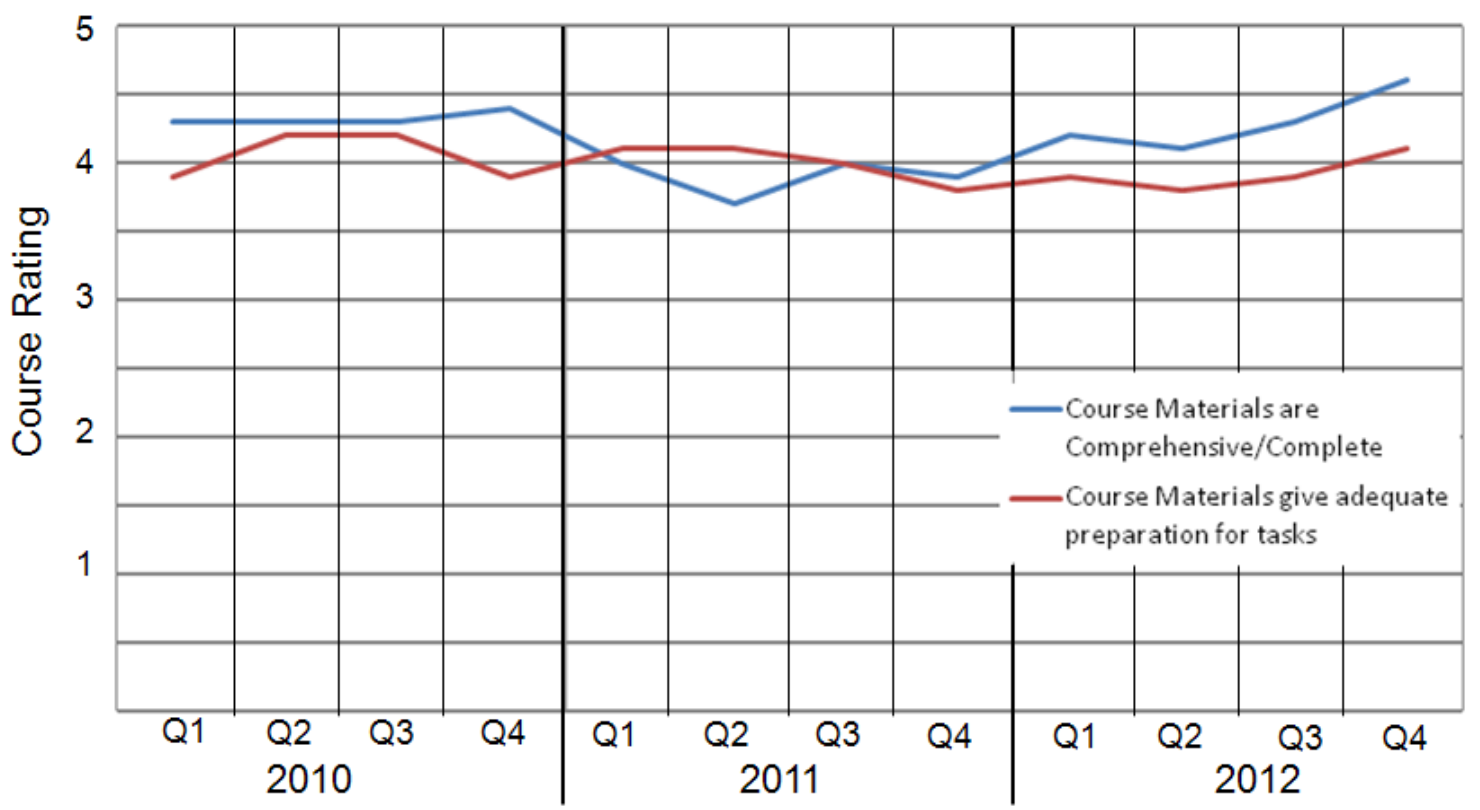

Figure 9: Course rating evaluations for SLAC's Laser Lessons Learned class. The ratings plotted are the average ratings from students who completed the course in a given quarter. A 1-5 scale is used for the effectiveness/quality of the training; 5 means strongly agree that the training achieved the stated goal, 3 is neutral and 1 means strongly disagree that the training achieved the stated goal. 